\title{
The Civil Liability of Credit Rating in China
}

\author{
Lin Wang \\ Zhejiang University \\ Hangzhou, China
}

\begin{abstract}
As a third-party institution for market risk disclosure, credit rating agencies should act as gatekeepers in the capital market. The improper arrangement and negligence of institutional arrangements make it possible for rating agencies to evade the burden of civil liability after multiple failures. By referring to the experience of western regulatory reforms and combining with the current status of China's legislation, the responsibility of credit rating agencies is defined as expert responsibility, and the restoration, compensation and deterrence of civil liability mechanisms is brought into play, which is of significance in reducing the failure of assignable liability and protecting investors' rights and interests.
\end{abstract}

Keywords-Credit rating; Rating failure; Accountability; Expert responsibility

\section{INTRODUCTION}

With the globalization of financial markets and the establishment of multi-level capital markets, the importance of China's credit rating industry to the capital market has become increasingly prominent, and the impact on investors has also increased. The business characteristics and business scope of each rating agency can be roughly divided into the following three categories. The first category is credit rating companies that have developed from the market and are relatively more standardized and independent in operation. The second category is the internal rating agencies originally subordinate to the People's Banks and other commercial banks at various levels. Originally, these institutions were mainly attached to banks and their businesses were relatively simple. At present, the number of such rating agencies is relatively large, the scope of business is relatively small, and the market has little influence. The third category is that foreign rating agencies have begun to actively develop the Chinese market. However, China's legislation has not specifically made institutional arrangements for the civil liability of credit rating agencies, leading to irrational and unclear rights and responsibilities of credit rating agencies, and in particular the lack of investigation of civil liability after adverse consequences of credit rating. The responsibility assumed by the credit rating agency should be defined as the category of expert responsibility. Therefore, it is imperative that we draw on the dialectical reference of international regulatory reforms, improve the civil liability system of rating agencies as soon as possible.

\section{NECESSITY OF INSTITUTIONAL ARRANGEMENTS FOR CIVIL LIABILITY OF CREDIT RATING}

The three major US credit rating agencies headed by Moody's Ratings Inc have always been giants of the capital market. They not only have "double monopoly status" but also have the privilege of "regulatory license". It is precisely because of the ratings of regulators and investors that a sudden financial crisis has pulled ratings agencies down and entered judicial proceedings. [1]At the beginning of 2013, the U.S. Department of Justice officially filed a civil lawsuit against Standard \& Poor's, accusing it of overvaluation of structured financial products such as debt-backed bonds before the financial crisis, leading investors to lose billions of dollars. Recently, the United States and the European Union have successively introduced a series of regulatory reform bills, many of which involve many adjustments to the credit rating behavior, thus breaking through the traditional paradigm that has long been hampered by internal corporate governance, and instead focusing on the external governance environment- the "gatekeeper" mechanism. Among them, the strengthening of civil liability is the common highlight and contention of these bills. In many cases, developed countries in the Western capital markets have established a relatively complete system of civil liability for credit rating agencies, which can be used for reference. From the perspective of legal prevention, a sound civil liability system for credit rating can provide reasonable expectations for the behavior of rating agencies, and avoid the occurrence of imputable rating failures as much as possible. From the perspective of compensation and recovery of civil liability mechanisms, it can also provide investors with practical judicial relief and establish confidence in the capital market [2]. 


\section{THE CIVIL LIABILITY OF CREDIT RATING FAILURE: IMMUTABILITY}

There is an essential difference between an inaccurate credit rating and a false credit rating. The inaccuracy of the rating result does not mean that the rating agency's behavior is illegal. Therefore, in the setting of the liability mechanism of the rating agencies, the underlying causes of failure should be categorized differently. For objective and unavoidable reasons, it may be considered in the design of liability as a violation of law. What the law needs to focus on should be based on the failure of ratings caused by faults. It is similar to force majeure and emergency hedging. Although both cause legal damaging consequences and infringe on legal interests, the law can be exempted from its responsibility. [3] Of course, it is necessary to consider the subjective fault of the actor, such as whether to take the necessary measures to minimize damage, whether to take proportional actions (ie, to take the least damage). Therefore, in order to avoid the setting of civil liability fall into the paradigm of "result imputation", it is extremely necessary to analyze the causes and behavioral process of rating failure.

\section{THE IMPERFECTION OF CIVIL LIABILITY SYSTEM OF CREDIT RATING}

After the financial crisis, the financial supervisory authorities of Western countries not only ended the status of the "extracorporeal circulation" of credit rating agencies, but also formulated relevant laws and regulations stipulating their civil liabilities. The provisions concerning the civil liability of credit rating agencies have gone from scratch, from the principled provisions to the enhancement of operability. The "Wall Street Reform and Consumer Protection Act of 2010", "Dodd-Frank Act" formulated by the United States, and the "Rules on the Supervision of Credit Rating Agencies" of the EU in 2013 related to the provisions on the civil liability for credit rating, and the absence of specific legislation. For the blank of judicial practice in China, it can provide a model for the institutional arrangement of civil liability of credit rating agencies in China. [4]

Credit rating agencies were once positioned as news media and protected by the First Amendment to freedom of speech. Moreover, section 18 of the 1934 US Securities Exchange Act requires lawyers, accountants, underwriters, etc. to assume legal responsibility when making false statements, except that credit rating agencies are excluded. The reason is that credit rating agencies are considered to be special media. They only collect, analyze, and publish financial information with news value, and do not constitute buying and selling suggestions. However, from the functional analysis of credit ratings, positioning a credit rating agency as an expert is undoubtedly more reasonable. First of all, the rating agency evaluates the solvency of the subject under evaluation, providing not only the facts, but also the viewpoints with subjective judgments. Second, the ratings that are made by the credit rating agencies are charged to the objects that are being rated, while news media are not charging the target audience, and they represent more of social welfare. Third, the credit rating not only affects the users of the rating report, but also affects the financing behavior of the rated target. The closeness of this connection is also different from that of the news media. The recent judicial practice in the United States shows that the court is no longer simply applying the First Amendment to the civil compensation cases of the relevant rating agencies. Instead, the judgment is based on the specific circumstances of the case. The main criteria for judgment include: Nature of business, initiative Still passive rating, representative of interests, whether to actively participate in transaction construction, credit rating agencies engaged in information publishing or financial product rating, is the issuer commissioned rating or active rating, credit rating results are disseminated to the public in the report issued by rating agencies It is still trusted by the public as a financial product distribution material. [5]There are also similar defenses in China that exclude expert responsibility. For example, the credit rating has a disclaimer on the rating report: it has no direct influence on the investor's decision, and the rating result is only a subjective statement that does not involve judgment on the facts. However, if the above disclaimer is placed under the framework of expert responsibility, it can be effectively refuted. Credit rating as a highly professional activity, its basic premise of existence comes from its professionalism and the trust of investors. Therefore, the so-called "investor's advice" does not constitute an effective defense against the trust benefit protection. In addition, the disclaimer can also be understood in the context of a format contract. If it is a violation of the fairness principle, it is improper to exonerate its own responsibilities, and the aggravation of the other party's responsibilities must not take effect.

\section{PROPOSAL OF INSTITUTIONAL ARRANGEMENTS FOR THE EXPERTS RESPONSIBILITY OF CREDIT RATING}

Our country has relatively perfect regulations on the professional liability of accountants, lawyers and other fields, but the credit rating field is facing the omission of the civil liability system. Therefore, a unified credit rating expert responsibility framework should be established to establish a unified liability system for future civil liability in the credit rating field. Since expert behavior has its own particularities in different fields, the general rules of applying civil law and tort law often fall into certain litigation obstacles. According to the "Securities Law" 173, China's positioning of the rating agencies within the securities market is in line with the responsibility of experts. Therefore, we may refer to the model 8 of Securities' Article 173 to establish an expert responsibility framework in the field of credit rating to enhance the litigability of rights. Specific improvements can be made from the following aspects:

Credit ratings often contain more complex legal relationships, clarify legal relationships under different models, and determine different claims bases, which will help investors and rated companies choose a more favorable relief path. The legal basis for supporting claims in the legal relationship of credit rating mainly includes contract and infringement. In the legal relationship between rating agencies and investors, because the issuer's payment is currently the dominant model, there is generally no contractual relationship between rating agencies and investors. Damage caused by failure of rating can seek remedies through infringement claims. [6]If expert responsibility is positioned as a contract liability, it is a 
limitation to rely on breach of contract as the basis of the right of claim. The principle of relativity of the contract often limits investors' right to appeal. Moreover, the contract area uses the principle of autonomy as the primary principle. The losses that can be encountered at the time of contracting are the basis of the scope of contract damages. However, in the capital market, the foreseen ability of the counterparty of the contract is limited. The responsibility of the contract is limited by the terms of the contract, and it is often difficult to obtain effective remedy for the failure to foresee at the time of the conclusion of the contract or the liability of the party to circumvent it.

The issue of the subject matter of the litigious litigation mainly needs to be clearly defined by the scope of the third party in the absence of a contractual relationship between the expert (credit rating agency) and the third party (investor). Because there is often a contractual relationship between the rated object and the rating agency, the determination of the litigation subject is generally not controversial. In the context of credit rating, experts must be accountable to a third person. The legitimacy lies in the following: First, the protection of trust interests. The main body of the capital market is the investor. Although the rating business is paid by the issuer, the ultimate audience is the majority of investors. Only by fully protecting the trust interests of investors can we truly accumulate reputational capital. Second, fulfill the "gatekeeper" mission. If the expert only considers his relationship with the client, the expert opinion loses its significance in legal communication. If credit rating agencies are the tools for issuers to implement financial products, the socalled "gatekeepers" in the capital market will be unable to talk about them. Third, it contributes to healthy competition in the rating industry. By establishing responsibilities to third parties and forming a mandatory binding force on the fulfillment of fiduciary obligations and diligent duties, it is possible to avoid race to the bottom [7].

Based on the highly professional nature of rating behavior and the confidentiality of information involved, it is difficult for investors to prove that the cause and effect relationship is difficult. Therefore, it is more appropriate to apply causality presumption for the determination of causality. It may wish to adopt the theory of market fraud in the world and combine the relevant content of the trust presumption principle to adopt a statutory presumption to judge the causal relationship between the false rating and the investor's economic loss. At present, in the legal liability for false statements in the securities market, Articles 18 and 19 of the Supreme People's Court's Several Provisions on Hearing Civil Compensation Cases Triggered by False Statements in the Securities Market carried out positive and negative determinations of causation. As long as relevant facts exist, it can be assumed that there is a causal relationship between false statements and damage results. Through the unification of the causality of the civil liability of credit rating, it is possible to avoid repeated use of theoretical evidence to waste litigation resources [8].

\section{CONCLUSION}

From the perspective of legal prevention, perfecting civil liability for credit rating can provide reasonable expectations for the behavior of rating agencies, and avoid the occurrence of imputable rating failure as much as possible. From the perspective of compensation and recovery of civil liability mechanisms, it can also provide investors with practical judicial relief and establish confidence in the capital market.

First, it shows respect for private rights and protects investor's right to appeal. All along, China has placed more emphasis on the public power of the countries in the market. Its obligations and responsibilities to the market entities have mainly manifested itself in public-law obligations, making civil liability tend to be imperfect. The emphasis on the construction of civil liability does not simply regard it as an economic compensation, but also embodies the respect of the private rights of market players. Again, play a deterrent role. "The function of civil liability is mainly the function of recovery. In addition, it has the function of prevention and the function of punishment. It is the function of the latter two kinds of functions, and it has received less attention." The development experience of the West is enough to reflect the low illegal cost and it is difficult to stop the infinite expansion of the desires of the rating agencies. The huge amount of civil compensation in the capital market not only restores the loss of investor rights, but also serves as a deterrent to rating agencies. Finally, play a regulatory assistance role. In fact, one of the themes considered repeatedly by US courts is whether the SEC has sufficient resources to monitor all crimes. With limited supervision costs, private compensation lawsuits are obviously efficient for the enforcement of laws. Therefore, the litigability of rights is strengthened, the civil liability system is improved, and market entities are more keen to identify those who are at fault under the impetus of interest. Undoubtedly, efficient supervision and assistance can be realized. "Without remedy, there is no right." For investors who have suffered losses by relying on the rating results, the current system of responsibility is not sufficient to fully protect investors' rights and interests. Therefore, a specialized civil liability system for credit rating should be established as soon as possible in specialized legislation or judicial interpretation so that the losses of investors' interests can be compensated in the future and judicial and substantive justice can be truly realized. 


\section{REFERENCES}

[1] Partnoy, Frank. "Siskel and Ebert of Financial Markets: Two Thumbs Down for the Credit rating Agencies." Wash. ulq 77 (1999),p. 623

[2] Hill.Claire A. "Rating Agencies Behaving Badly: The Case of Enron." Conn. L. Rev. 35 (2002),p. 1149

[3] John C.Coffie." Gatekeeper Mechanism: Market Intermediary and Corporate Governance.” Peking University Press(2011),p.334

[4] Luo Peixing." The Perfection of Legal Responsibility of Credit Rating Agencies in Post-crisis Era." China Legal Science7(2009),p.78. (In Chinese)

[5] Nie Feizhou." Rethinking and Enlightenment of Legal Responsibility of American Credit Rating Agency__From the Perspective of Judicial Precedent." Oriental Law.6(2010), p.56. (In Chinese)

[6] Zhao Lei." Legal Governance of Failure of Credit Ratings: Implications of the US Subprime Mortgage Crisis in China." China University of Political Science and Law Press.7(2013),p,354. (In Chinese)

[7] Zhou Youjun.’The normative pattern and specific rules of the expert's responsibility to third parties."Contemporary Law Review."1(2013),p.45. (In Chinese)

[8] Meng Xiangtao."The Latest Development of the Supervision of EU Credit Rating Agencies and Its Enlightenment to China." FinancialLawForum.2014, p.263. (In Chinese) 